\title{
ReSEARChArticle
}

\section{Performance of capsicum hybrid mekong under different plant spacing and fertigation schedules}

\author{
JASBIR SINGH SANDHU, AMARDEEP SINGH BRAR AND PRABHJOT SINGH
}

\begin{abstract}
SUMMARY
A field experiment was conducted using treatments, viz., spacing $\left(\mathrm{S}_{1}=60 \mathrm{~cm} \times 30 \mathrm{~cm}, \mathrm{~S}_{2}=45 \mathrm{~cm} \times 30 \mathrm{~cm}\right)$ and fertigation $\left(F_{1}=\right.$ fertigation twice a week @ 2g NPK $(19: 19: 19) / \mathrm{m}^{2}$ and $\mathrm{F}_{2}=$ fertigation thrice a week @ 2g NPK $\left.(19: 19: 19) / \mathrm{m}^{2}\right)$ in Factorial Randomized Block Design with three replications under polyhouse conditions. One month old seedlings of hybrid Mekong were transplanted at the above spacing and fertigation was applied three weeks after transplanting and was applied @ 2g/ $\mathrm{m}^{2}$ area twice and thrice a week NPK, respectively through water soluble fertilizer (19:19:19). Fertigation was stopped fifteen days prior to final harvesting of fruits. Treatment comprising spacing of $60 \mathrm{~cm} \times 30 \mathrm{~cm}$ and fertilized thrice a week was significantly superior to other treatments with regard to plant height, average fruit weight, fruit length, yield per plant and yield per square meter.
\end{abstract}

Key Words : Capsicum, Hybrid Mekong, Fertigation schedules, NPK

How to cite this article : Sandhu, Jasbir Singh, Brar, Amardeep Singh and Singh, Prabhjot (2016). Performance of capsicum hybrid mekong under different plant spacing and fertigation schedules. Internat. J. Plant Sci., 11 (2): 337-339, DOI: 10.15740/HAS/IJPS/11.2/ 337-339.

Article chronicle : Received : 17.04.2016; Revised : 27.05.2016; Accepted : 24.06.2016

\section{MEMBERS OF THE RESEARCH FORUM}

Author to be contacted :

AMARDEEP SINGH BRAR, Department of Vegetable Science, C.S.K.

Himachal Pradesh Krishi Vishvavidyalaya, PALAMPUR (H.P.) INDIA

Email: goodbrar@gmail.com

Address of the Co-authors:

JASBIR SINGH SANDHU AND PRABHJOT SINGH, Department of Vegetable Science, C.S.K. Himachal Pradesh Krishi Vishvavidyalaya, PALAMPUR (H.P.) INDIA 